\title{
THE CONTINUING RELEVANCE OF LATE DR W. E. B. DU BOIS TO AFRICAN SCHOLARSHIP
}

\author{
Shaka Yesufu ${ }^{l}$ \\ ${ }^{1}$ Department of Research and Development, University of Limpopo, Limpopo Republic of South Africa \\ E-mail:Shakazulu17@yahoo.co.uk \\ ORCID: https://orcid.org/0000-0001-8002-3074
}

ARTICLE INFO

Article history:

Received date 14.09.2021

Accepted date 19.10.2021

Published date 29.10.2021

Section:

Communication Studies

D O I

$10.21303 / 2313-8416.2021 .002126$

KE Y W ORD S

Pan-Africanism

Colonialism

Racism

Post colonialist

African Renaissance
ABSTRACT

The objects of this research are: first, to explore the uniqueness and visionary thinking of Dr W. E. B. Du Bois concerning the concept of race and racism over time. Second, to highlight the socio-economic conditions and disempowerment of blacks living in different countries of the world. Third, is an attempt to review his work and its relevance to African scholarship by using the qualitative research method, enabling us to understand the philosophical impetus arising out of his valuable contribution to African scholarship.

The author investigated the following problems: social problems, caused by racism, discrimination race, exploitation, black disempowerment, inequality, and social justice.

The main results of the research are: The findings of this study are: first, the importance of unity of the Africa people is crucial for its development. Second, the implementation of educational policies, political leadership, a vibrant economy, and the establishment of the military to protect Africa's global interests are all very important for its survival and development. Third, is the highlighting of the level of grave injustice faced by both Dr Du Bois and his wife in the hands of the US law enforcement services. Fourth, it was found that the African continent is not economically independent. Fifth, it is only through the unity of African peoples and countries that it can eventually lead to its development and progress.

The area of practical use of the research is for all citizens, directly or indirectly affected by race, racism, disempowerment, and social inequalities that still permeate contemporary societies.

(C) The Author(s) 2021. This is an open access article under the Creative Commons CC BY license

\section{Introduction}

\section{1. The object of research}

The objects of this research are: first, to explore the uniqueness and visionary thinking of Dr W. E. B. Du Bois concerning the concept of race and racism over time. Second, to highlight the socio-economic conditions and disempowerment of blacks living in different countries of the world. Third, is an attempt to review his work and its relevance to African scholarship by using the qualitative research method, enabling us to understand the philosophical impetus arising out of his valuable contribution to African scholarship.

\section{2. Research Problem}

This article seeks to explore and revisit the importance of the academic legacy bequeathed to us by Dr W. E. B. Du Bois. His invaluable contribution to the African scholarship is uncontested and unrivalled by many academics who came before and after him. Dr William Edward Burghardt Du Bois was born on (February 23, 1868 - August 27, 1963), an American civil rights activist leader, a Pan-Africanist, sociologist, educator, historian, writer, editor, poet, and an academic scholar par excellent. Dr W. E. B. Du Bois was born in Great Barrington, Massachusetts, United States of America. He obtained a Bachelor of Arts degree from Fisk University in Nashville, Tennessee, in 1888. In the same year, he entered Harvard University as a junior, taking a Bachelor of Arts cum laude in 1890. In 1891. Dr W. E. B. Du Bois obtained a Master of Arts degree and from 1892-1894 he pursued his graduate studies in history and economics at the University of Berlin. He was awarded his doctorate in history from Harvard in 1895. Dr Du Bois worked for the National Association for the Advancement of Colored People (NAACP) for 24 years. He represented the organization at the first meeting of the United Nations in 1945. In 1959, Dr. Du Bois received from the Soviet Union the Soviet Lenin Peace Prize "for strengthening world peace." A biography of 
Dr W. E. B. Du Bois is required for this study. The author provides readers with a brief biography of Dr WEB Du Bois. This affects the research in two ways. First, due to the generational gap between most of the readers and Du Bois, many would not know much about him or recognises his valuable contribution to knowledge. Second, a biography of Dr Du Bois will fill the expected academic lacuna created by the identified generational gap. The author argues that even if some of Dr Du Bois's works like the Philadelphia Negro (1898), Conservation of Race (1904) were published over 100 years ago. The deprived social conditions of blacks living in the United States still face similar circumstances of social inequalities [1,2].

The author identifies some of the following gaps: first, that little attention was paid to the extent of the level of hostility and persecution faced by Dr Du Bois in the hands of the United States of America law enforcement agencies highlighting America's hypocrisy as the land of the free [3, 4]. Second, little or no attention is paid to acknowledging his wife's Ms Shirley Graham - Du Bois's relentless support [5]. The author seeks to fill some of these identified academic gaps.

Dr Kwame Nkrumah also referred to Dr Du Bois as a person of "extraordinary phenomenon"; "the father of Pan-Africanism". Pan-Africanism as the author understands it is an ideology and movement that encourages the solidarity of Africans vital to economic, social, and political progress which aims to uplift all peoples of Africa descent. The destiny of all Africa peoples irrespective of their countries of origin is inextricably linked and intertwined. Pan-Africanism is the juxta-positioning and the redefinition of the African identity and personality contrary to the oldheld black people's Eurocentric myths of savagery and barbarity [6, 7].

\section{3. Suggested solution to the problem}

The African-American sociologist Dr W. E. B. Du Bois was the first scholar to elaborate sociologically the argument for the social-cultural rather than the biological or genetic conceptualization of race. Du Bois [8, 9]. Dr W. E. B. Du Bois provides us with the meaning of double consciousness concerning understanding the concept of race. According to Dr Du Bois, double consciousness can be gleaned from two angles: First, it can be perceived from the real power of white stereotypes and the internal psychological conflict faced by the African American individual between what was 'African' and what was 'American', an individual caught up in a dilemma between two opposing cultures and values; second, double consciousness can also be seen as a mythic blessing and a social burden, a struggle to distinguish between an outsider and insider in social, economic and political contexts [10].

Dr W. E. B. Du Bois offered some original and authoritative insights into the problem of the mechanisms sustaining racial discrimination which to this day inform the debates about this phenomenon. Dr Du Bois was the first to elaborate sociologically the argument for the social-cultural rather than the genetic understanding of race. Du Bois in his essay, 'The Conservation of Race' [11]. he gave a clear definition of race as the community of language, history, and social habits of people who consciously or involuntarily strive to accomplish certain goals in life. Zuckerman [12]. In his attempt to explain a high incidence of crime among African-Americans, Dr Du Bois pointed to the socio-economic conditions and overall marginalization of this group as the circumstances primarily responsible for this phenomenon. Together with deeply embedded white representations of blacks as a "lower species," African-Americans' low socio-economic position and civil-political disempowerment - in no small part the result of their exclusion from mainstream American society and, in particular, its economic opportunity structure and the operation of the (white-only) liberal democracy - account for the persistence and legitimation of racial discrimination against blacks by white Americans [13, 14]. Until this oppressive constellation of cultural and socio-economic circumstances, African Americans found themselves in was broken down, Du Bois argued, Negroes were faced with a no-win situation and had only three choices:

- submit permanently to an inferior position with a painful "double consciousness" trying to negotiate two separate, black and white worlds;

- die out;

- emigrate [15].

In the aforementioned critical works, Dr W. E. B. Du Bois exposes the United States of America's hypocrisy, particularly in terms of giving opportunities to its black citizens. His immense contribution to the political and economic emancipation of African countries is well evi- 
denced in his writings and speeches. Dr Du Bois organized a series of Pan-African Congresses around the world in 1919, 1921, 1923, 1927, and 1945. Items on the agenda discussed at these Conferences included the following issues: social, political, and economic conditions of blacks in the diaspora; the importance of independent African nations governed by people of African descent; the legacy of slavery and European imperialism; the role of Africa in world history; and the impact of Christianity on the African continent. The researcher argues that 100 years after these conferences, the issues that were discussed then remains relevant to many of us in Africa.

The Niagara Movement was a civil group founded in 1905 near Niagara Falls. Dr W. E. B. Du Bois gathered with supporters on the Canadian side of Niagara Falls to form an organization dedicated to social and political change for African Americans. Its list of demands included an end to segregation and discrimination in unions, the courts, and public accommodations, as well as equality of economic and educational opportunity. The Niagara Falls movement heralded a major step on the road to black militancy in America

Adejumobi [16]. argues that Pan-Africanist ideals emerged in the late nineteenth century in response to European colonization and exploitation of the African continent. Pan-Africanist philosophy held that slavery and colonialism depended on and encouraged negative, unfounded categorizations of the race, culture, and values of African people. These destructive beliefs, in turn, gave birth to intensified forms of racism, the likes of which Pan-Africanism sought to eliminate

The author provides here some of Du Bois' philosophical premises. They are as follows:

1. Africa has been unjustly devalued and humiliated over the years (the Hamitic hypothesis stated that African genealogy can be traced back to Ham, the cursed son of biblical Noah. It is seen as the 'dark' continent with no civilization and is inhabited by 'savages' and 'barbarians' [17].

2. Africans at home and abroad share a common destiny and the African personality that binds us together is worth preserving in the face of oppression and brutalization by other races.

3. Africans should be free to govern themselves and to form a continental political union as a defence against imperialist exploitation.

4. The White man is always right and the Black man has no rights that a white man is bound to respect [18].

In his final submission to the Pan-African Conference in Manchester, England, in 1945, Du Bois urged delegates from colonized parts of the world to unite and assert their rights to reject those imperialists seeking to control their destinies; he encouraged them to elect their respective governments and realize that emancipation of the African people was a precondition for their human development and social wellbeing. Recognizing Du Bois's historic contribution to the Pan-African movement, delegates honoured him as president of the 1945 Congress. Pan-Africanism conferences were important because they were designed to fight racial domination on two fronts: On one side, challenging racism and racial injustices in America and, on the other front, fighting for the total decolonization of the African continent. In 1961, he relocated to Ghana where he was appointed director of 'Encyclopedia Africana', a publication geared to the rewriting of Africa's skewed history. The researcher believes that Dr Du Bois's return to Africa is not only symbolic in the physical realm but also had a deep spiritual significance. His great grandparents were forcibly removed from Africa and were taken as slaves to America. He voluntarily returned to Africa to complete his life's journey and to be reconciled with his ancestors. Du Bois aptly summarized his coming home to his roots (Africa) as "I have returned so that my remains may mingle with the dust of the forefathers" [19].

For these reasons, Africans should hold Dr Du Bois in very high esteem and accord him the great admiration that he deserves. He was a true son of Africa who never lost sight of the calling of mother Africa. Unarguably, Dr Du Bois, for many of us living in the Africa continent remains a source of inspiration and beacon of hope for all oppressed peoples of the world especially those living in the diaspora. His philosophy empowers us in academia to challenge the injustices in our society without fear of recrimination and if need be, to be prepared to pay the ultimate sacrifice for one's profound values of a better humanity, equality, and justice.

The author argues that Du Bois was instrumental in providing intellectual guidance for African leaders who attended the Pan-Africanist conferences. These included leaders such as Jomo Kenyatta (Kenya), Kwame Nkrumah (Ghana), and Dr Nnamdi Azikiwe (Nigeria) who later fought and gained independence from the British colonial governments and played a major role in the 
formation of African Unity in May 1963. One can safely argue that Du Bois was instrumental in providing a blueprint for the decolonization of the African continent by first providing a link and then bringing together black African Americans living in the diaspora and black people living on the African continent. The author argues that William Du Bois provided the Africa diasporas with the missing link and sense of connectedness between blacks living on the African continent and blacks living in the diaspora, specifically African Americans.

As a scholar, Du Bois's most lasting contribution is his classic academic writings. He wrote 21 books, edited 15 more, and published over 100 essays and articles. From 1934-1944, Du Bois was chairman of the Department of Sociology at Atlanta University. He wrote 'Black Folk, Then and Now (1939), an elaboration of the history of black people in Africa and the New World, Colour and Democracy. Early post-war followers of Du Bois' ideas tended to reduce his multi-dimensional interpretation of the persistence of racism by emphasizing single - cultural or economic - explanatory factors It was only in the 1980s, with the revival of interest in race and racism in Europe and, specifically, British sociology, that the reductionist, cultural or economistic interpretations of racism were challenged and the Du Boisian multi-dimensional approach to the explanation of this phenomenon revived. Of greatest influence among scholars who have shared this perspective has been the work of John Rex. In his Race Relations in Sociological Theory 1970 [20] traces the phenomenon of racism to the historical process of the colonial expansion of Europeans - here, the British - and explains the persistently subordinate position of blacks in terms of their relation to the currently dominant means of production.

W. E. B. Du Bois declared that the colour line would be the problem of the $20^{\text {th }}$ century. The author argues that, here, in the $21^{\text {st }}$ century, the world is still divided along racial lines, and by tribal conflicts, civil strife, xenophobia, terrorism, racial hostilities, and the construction of the 'other'. All these problematic issues have become a worrying development for humanity because there is no lasting solution insight that might enable us to unite together as peoples of the world. Dr Du Bois not only faced direct racism in the wider society but also faced racism within academia [4, 21]. He encountered racism when he was in the process of writing a scientific study titled 'the encyclopedia of the Negro' which was a voluminous book. Prominent amongst white academics who were overtly racist and critical of Dr Du Bois's work is the American academic Melville J. Hertkovis who argued that 'African-American were beneficiaries of an African cultural heritage that had survived the vicissitudes of slavery and Jim crow. Slavery never destroyed Africa culture but rectified it and made it more civilized and more acceptable. The author argued that first, Hertkovi's argument is misleading and deeply flawed. The degrading process of name changing of slaves by their masters and been forced to abandoned one's language is like stripping off their human social identity. Such mistreatment has sustained the stigma of the inferiority of black African Americans to this day many are still seen and treated as sub-human beings globally. Hertkovis like many of his white folk in sustaining their racial superiority claim to knowledge argued that 'black scholars could not be trusted to conduct objective scholarship on black and race because they were too emotionally evolved with these topics which violate basic scientific law to mixing activism with scholarship. They need to be supervised by white academics’ Herrnstein \& Murray [22].

The generational unanswered question is this: To whom do we turn for the unity of the human race?

Du Bois argued in Philadelphia Negro [12] that 'Racism makes it difficult for black men to earn a living or spend their earnings as they will, it gives them poorer school facilities and restricted contact with cultured classes, and it becomes, throughout the land, a curse and excuse for discontent, lawlessness, laziness and injustice' In this text, Du Bois exposes American society, which treats its black citizens in a very disdainful way and consigns them to inhuman conditions but also wants to be seen at the same time as champions of democracy in the world. Du Bois argued that this is a misrepresentation of the true nature of things and of what it means to be a black African living in the United States. The author argues that Africa must rise to clean up the remnants of neo-colonialism with exploitative tendencies designed to hamper the growth and development of the Africa continent. Africa should be very cautious and suspicious of countries queuing up to tap both their natural and human endowed resources under the guise of development. The likes of [23-25] have all argued that Europe has underdeveloped Africa. The researcher argues that Africa can trade with other countries but should not allow the history of exploitation and underdevelopment to happen 
again. Dr Du Bois fought against the negative stereotyping of black people, challenging the labelling theory that described black people as lesser human beings, less intelligent, and uncivilized. Dr Du Bois and other Afrocentric writers such as Kwame Nkrumah of Ghana debated the early history of human civilizations and argued convincingly that civilization started in Egypt and not in Europe as widely proclaimed by Eurocentric writers.

Nkrumah [26] argued that even after African countries were given independence, most of their economies were still subtly controlled by their colonial masters. The author argued that it is high time we must also start to accept some responsibility for our problems in Africa today, marred as it is by a catalogue of corrupt leaders, civil wars, religious wars, terrorism, and tribal conflicts in Liberia, Sierra Leone, Rwanda, Congo, Uganda, Kenya, Somalia, Sudan, Mali, Libya, Niger, and Nigeria. Africa needs to live in peaceful co-existence rather than waging unnecessary wars that hinder its development.

Nkrumah (1974) warns of the dangers of neocolonialism in Africa and the developing world. He argues that "Neocolonialism is also the worst form of imperialism. For those who practice it, it means power without responsibility, and for those who suffer from it, it means exploitation without redress... A state in the grip of neocolonialism is not a master of its destiny. It is this factor that makes neocolonialism a threat to world peace... Neocolonialism is a millstone around the necks of the developed countries which practise it. Unless they can get rid of it, it will drown them" [27].

Inspired by the arguments of Nkrumah stated above, the author is persuaded that never in Africa's history has African unity been so essential than today. One hopes that the African Union will move towards a new paradigm shift or impetus needed to bring about some desired radical changes such as peace and stability in the continent, infrastructural developments, improvements in trade, technology and energy, education and health, the alleviation of poverty and disease in Africa, and the continuing fight against AIDS and all deadly diseases in the African continent. The author argues that all 54 nations of Africa should facilitate a platform for international trade with one another, and to develop transport and communications infrastructures with each member state.

In response to the calling of African academics to promote African identity and to redefine and reconstruct what it truly means to be African. Gutto[28] articulates that:

"The Knowledge about Africa and Africans that most have been taught or consume in other ways is constructed from the perspectives of those who have made it their historical mission-driven by material interests, racism, and a quest for power- to distort, confuse, disorientate, fragment and subordinate and exploit Africa and Africans wherever they may be. Even where Africans have contributed some knowledge about Africans and Africa in human civilization, such contributions have largely been inescapably tainted and constrained by the paradigms learned from slavers, colonisers and neo-colonisers" [29].

Dr W. E. B. Du Bois called for a union of Black gifted scholars coming together to rub minds constructively and to take the leading role in providing both education and political leadership. Africa should not allow itself to be governed by the mediocre but should turn instead to talented individuals who are capable of developing strategies to incorporate marginalized blacks all over the world back into the mainstream of society [30]. There should be no room for political buffoons, mediocre, and dictators on the African continent to ascend to leadership. Africa should be driven by her gifted intelligentsia if meaningful progress is to be made. Dr Du Bois used the term 'the Talented Tenth "to describe the likelihood of one in a million black men becoming leaders of their race in the world, through methods such as continuing their education, writing books, or becoming directly involved in social change. The talented tenth is the cultivation of a class of exceptional leaders through classical education that was crucial to the emancipation and empowerment of black folks.

The aim of the research is to familiarize the reader with some of the philosophical arguments posited by Dr W. E. B. Du Bois in relation to how race and racism affects black people especially in today's United States of America.

\section{Materials and Methods}

The author relies on researching secondary data about Dr W. E. B Du Bois. Extensive literature reviews were conducted by the author.

Secondary data is a process of carrying out a systematic review of previous literature as it relates to the research topic. It relives the author the burden of participation with research partici- 
pants, who to identify, access to, and limited time frame available to conduct the research. In this study, the author collected secondary data from previous qualitative studies relating to the research topic. The author's main task was to ensure that the data analysed is not subject to any form of misinterpretation. In doing so, the researcher can rely on critical and reflective constant comparison of previous and present secondary data collected to arrive at an objective conclusion [31, 32].

\section{Results}

\section{1. Africa's Unity}

We must strive to promote Africa's unity and integration. There is much to be gained from the unity of Africa, regardless of the differences in our languages, cultures, and beliefs. The unity of Africa should be pursued vigorously by all nations and peoples of Africa. The mindset of the African must change from economic dependency on foreign courtiers to self-reliance. History tells us that Africa was carved up unlawfully by Western nations at the Congress of Berlin (1184-1185) where the scramble for and partition of Africa took place. Africa was divided up amongst world powers such as France, Britain, Germany, Portugal, and Belgium. This division between the French and British, for example, has led to language barriers that still exist in Africa today. For example, a person from Congo will find it difficult to understand a South African. In the same way, a Senegalese person will find it difficult to understand a person from Ghana due to colonial language orientation that was transferred and transmuted by their distinctive colonial masters.

This is further compounded by the fact that Africa has a very large number of different languages. The author argues that it is high time that Africa developed its uniform language. Many may be tempted to say that this is something best left to the linguists to sort out. The author believes that if there is a common language in Africa, Africa would be more united. We must not forget that the English language still widely used today is not the indigenous language of the African people. The language and the names we bear give us our social identity. We learned from Africa history that during the balkanization of the Africa continent, France pursued a policy of "assimilation" as part of their imperialist agenda. Thus, we have countries in Africa like Mali, Cameroun, Togo, Senegal, Ivory Coast still coming to terms with the loss of their indigenous languages substituted by the French language as a medium of communication. A common language in Africa will create an atmosphere of mutual understanding and progress.

\section{2. Education}

Dr W. E. B. Du Bois was a believer in life-long education. His educational credentials above attest to this fact. He argued as follows:

"We want our children educated. The school districts in the South are a disgrace. Education is the development of power and ideal. We want our children trained as intelligent human beings should be... We will fight all the time against any proposal to educate black boys and girls simply as servants and underlings or simply for the use of other people. They have a right to know, to think, and aspire... Either the United States will destroy ignorance or ignorance will destroy the United States... We want our children trained as intelligent human beings should be, we will fight all the time against any proposals to educate black boys and girls to be supplied as servants" W. E. B. Du Bois [25].

The author argues that Dr William Du Bois paved the way for many African scholars. Had Dr W. E. B. Du Bois failed when he was first admitted to Harvard, some of us would have continued to be doubted even more today and that as black people's our ability to contribute to knowledge would have suffered a major setback? Dr Du Bois proved a point to racial typologists of his generation then and now: that black people can hold and use knowledge constructively if the opportunity and time allow them to do so in any society.

In Africa, we have no integrated educational system. The pace of designing an educational curriculum differs from one country to another. For these reasons, coupled with a total failure of some African States to successfully invest enough in education, some of our educational systems in Africa are not fully up to speed. The author argues that most of our governments in Africa, to varying extents, have not focused sufficiently on education. In some parts of Africa, leaders have focused more on corruption than on investing in education. Corruption has hampered the develop- 
ment of the African continent, billions of dollars earmarked to build some African countries have ended up in African leader's bank account in Europe, and in different parts of the world.

Africa has a rich culture and traditions that are not celebrated frequently enough. Over the years, African customs have been widely portrayed by European colonizers under the guise of Christianity as 'ungodly', 'heathen', and 'barbaric' Achebe [28]. Achebe argued that the coming of white people to Africa was a divisive force geared to and responsible for the disintegration of the African indigenous people. Before the Europeans arrived in Africa, Africans had their own established medium of communication with their ancestral gods and divinities. African scholarship needs to encourage the telling of African history from an African perspective. Africa governments must make education a basic fundamental human right. Investment in education, science, and technology should be one of the top priorities of African governments. Educational facilities and an enabling environment to conduct high-quality scholarship and research should be established in all 54 countries of Africa. No country should be left behind in this proposed educational framework for moving Africa forward. African intellectuals should be at the forefront in promoting lifelong learning by facilitating research, debates, and ideas on Africa. Education in Africa should be made accessible to all regardless of one's social class or background.

The author is persuaded by the arguments presented by Gutto [33] that "Education in Africa needs a fundamental paradigm change which entails among other things, focusing on confrontation to correct and depart from hegemonic knowledge and knowledge systems that are predicated on racist paradigms that have deliberately and otherwise distorted, and continue to distort the reality of who Africans are... all Africans and peoples of African descent need to possess some basic shared common knowledge about Africa, the Diaspora, and the world- and to acquire critical approaches to contextualized learning".

\section{3. Political leadership}

The author argues that Africa is a continent of contradictions concerning the issue of political leadership. Africa has been blessed with several selfless leaders. African history tells us that good nationalist and patriotic leaders such as Abdel Nasser of Egypt, Ben Bella of Algeria, Jomo Kenyatta of Kenya, Kwame Nkrumah of Ghana, Nnamdi Azikiwe of Nigeria, Samora Machel of Mozambique, Patrice Lumumba of Congo, Thomas Sankara of Burkina Faso, and Nelson Mandela of South Africa, have all unarguably been accorded prominent places in Africa and world history. We also know that Africa has produced several very corrupt, tyrannical, and despotic leaders. Africa needs good governance and accountable leaders with vision and commitment to the citizens of Africa. Africa should not be seen as a dumping ground for mediocre leaders. African needs visionary and selfless leaders. Until the issue of good governance is successfully resolved in Africa, it will be problematic for Africa to achieve the desired progress.

\section{4. Economy}

Although most countries in Africa have attained their political independence, their economies have continued to be controlled by Western nations. [34, 35]. The researcher argues that, until the people of African achieve economic independence, Africa will not be fully emancipated from the colonizers. African scholars should make it a priority to ensure the complete decolonization of Africa, an aim the likes of Du Bois and Frantz Fanon were very keen to pioneer, and for which they fought for throughout their entire lives. Africa should devise trade mechanisms and processes that can promote the free movement of goods and services between all countries of Africa. Africa should not present itself as a tool to be used by imperialist powers who want to determine how and with whom Africans trade. Africa should decide its trading partners and its destiny. Africa has a mind of its own. The author proposes a continental Bank of Africa like the African Development Bank to make the exchange of goods and services less cumbersome. The African Union and NEPAD should be at the forefront of dismantling trade barriers amongst Africa countries. The author is not an admirer of the International Monetary Fund for three reasons. First, it has placed several African countries into greater debt due to unfair lending conditions. Second, it is not greatly troubled by the notion of dispatching funds to corrupt African leaders. Third, it does not check whether the allocated funds are used properly to develop the African people and continent. 


\subsection{Military}

Africa needs a standing army to counter the threats of imperialism and to deal with conflicts in Africa. The events that recently unravelled in Libya justify the need for a strong army in Africa. The West has NATO to protect its global interests. With the global economic downturn, Africa is more vulnerable than before. The Southern Development Community (SADC) Mutual Defence Pact states 'an armed attack against a State Party shall be considered a threat to regional peace and security and such attack shall be met with immediate collective action' [36, 37]. The SADC Standby force performs the following: monitoring and observing peace missions in Africa; acting as an intervention force; restoring peace and stability in Africa. It is important to mention here that the AU Peace and Security Council, African leaders, and the Military Staff Committee have already signed a policy document in July 2004 in Addis Ababa [6]. Other regional international bodies such as the ECOWAS have also established policies and modalities for having a standby force to deal with crises in line with African Union and United Nations guidance. The author argues that more military cooperation is needed to bring about peace and stability in Africa. The author argues that it is high time Africa considers forming a formidable military contingent to keep in check promoters of regime change. How do we revive and restore Africa from obscurity to its rightful place of global prominence? The researcher urges all members of Du Bois's 'talented tenth' to continue to work collectively and individually to make Africa a prosperous continent. Perhaps a good starting point would be to revisit the canonical works of William Du Bois for guidance. The author argues that history will not forgive him if he fails to mention the level of grave injustices and the persecution faced by Dr W. E. B. Du Bois in the hands of the US law enforcement agencies.

The Federal Bureau of Investigation (FBI) harassment of Dr Du Bois and his wife.

It was widely reported that one of the founding fathers of the NAACP founder W. E. B. Du Bois was investigated by the FBI for suspected Communist ties. In 1951, the Peace Information Center he was running was indicted as a suspected Communist "front" organization. The file contains coverage of this event and the last section consists of newspaper clippings about Dr Du Bois. During the cold war, 'the United States government deployed full state apparatuses against activists associated with the Black struggle. Federal security agencies linked social justice to fictitious treasonous conspiracy leading to several arrests, restriction of movements, and seizure of traveling passports [7]. In 1951, Dr Du Bois and his wife were arrested and indicted to be an agent of a foreign power the Soviet Union. Acquitted after a five-day trial. Both Dr Du Bois and his wife's traveling passports were seized by the United States government in 1952 and were returned to them six years later in 1958. Dr Du Bois declared his support for communism which he called the 'most hopeful country on earth', awarded a Russian Lenin prize for strengthening peace among peoples of the world. His association with communism led to his civil rights colleagues in the National Association for the Advancement of Colored People (NAACP) abandoning him and his ideas. Dr Du Bois and his wife were detained and deported from Canada back to the United States of America in 1952 whilst invited to attend a World Peace Conference. Dr Du Bois was constantly harassed by the US authorities. As a result of this and the resentment harboured by his former civil rights colleagues, Late President Kwame Nkrumah invited him and his wife to relocate to Ghana. More importantly for the safety of their lives. In 1963, whilst residing in Ghana, Dr Du Bois and his wife visited the US embassy to renew their passports but they were refused the opportunity to do so. Even at death in 1963, the US government continue to treat Dr Du Bois in a very outrageous and disdainful way. No delegation from the US embassy attended his funeral and no message of condolence was sent to his family [38]. In the next section, the researcher discusses and acknowledges the valuable contributions and the sacrifices made by Dr Du Bois wife, late Lola Shirley Graham -Du Bois. The researcher argues that many writers have paid little or no attention to her and her selfless support and contributions to the success of Dr W. E. B. Du Bois. The researcher acknowledges and recognizes this exemplary woman. To understand the valuable and outstanding works of Dr W. E. B. Du Bois, researchers must understand his supportive social structures as well [39].

\section{Discussion}

In this section, the author presents some of the advantages of the research and the future direction of the study. 


\section{Advantages of the study.}

First, the study highlights the issues arising out of race and racism. It has been a contentious issue that divided society for over a century and stills divide us today.

Second, the issue of critically discussing race is put back on the agenda. Third, it appreciates the value of Dr W. E. B. Du Bois's works in making us understand the issue of race from a disempowered position. Fourth, that no single race is created as inferior but a lack of economic opportunities and sustainability is crucial to understanding the position faced by black Africa Americans. It highlights the difficulty for black African Americans to gain equality after over 300 years of slavery. Fifth, it provides a platform for emerging African scholars to preserve the legacy of Dr W. E. B. Du Bois.

Future Directions.

Dr W. E. B. Du Bois's remarkable life history should be introduced into a proposed integrated educational curriculum, taught at schools, colleges and universities. The African Union should play a more proactive role in realizing this objective. The author argues that the more people study Du Bois's history in contemporary societies, the more likely his legacy will be preserved from one generation to another. The author argues that there is nothing wrong with having Dr W. E. B. Du Bois's day in the African continent similar to Dr Martin Luther King Jr. day in the United States. Celebrating his life will keep Dr Dubosi's legacy alive.

Limitations of the study.

Globally, only a few academics appreciate the works of Dr Du Bois. First, several people view some of his polemic writings and philosophical ideas as too divisive and controversial in today's society where multiculturalism has become more acceptable. Second, Du Bois's essays are predominately related to race, racism, and social justice, many people do not want to talk about race or racism in contemporary societies. Third, Du Bois's arguments and ideas were written over a century ago. Many would argue that the American of a century ago is not the same as today. The works of Du Bois continue to seek global recognition even after he is gone. Further researches on Dr WEB Du Bois are needed because there is room for the generation of authors coming after me to evaluate and to understand the relevance of Du Bois scholarly contribution to social justice, equality, and justice. More importantly, promoting research about Dr W. E. B. Du Bois will enhance the preservation of du Bois's legacy.

\section{Conclusions}

1. The author looks at some of the works of Dr Du Bois and argues that it remains relevant to contemporary African scholarship. Dr Du Bois's work highlighted the plight of black people subjected to racial oppression and injustices in the United States of America. The author argues that even in today's America, black people are still not treated as equal to their white folks. The author provides the reader with several examples of where law enforcement officers killed black people in the glaring eyes of citizens.

2. The author in the study looks debunking Dr Du Bois being labelled a communist, even though he was, the author argues that does not warrant the level of persecution, oppression, and harassment melted on him and his wife until they are no longer able to cope with it. Even whilst they were in exile in Ghana, Africa. The United States law enforcement agencies did not let go of $\mathrm{Dr} \mathrm{Du}$ Bois and his family. The author argues that for a country such as the United States that prides itself as defender of democracy, freedom, and justice. It becomes a misnomer or hypocrisy when we look at how the US treats its black citizens taken into cognizance how Dr WEB Du Bois and his wife were hounded out of the United States.

3. The author emphasizes unequivocally, that Africa's unity is a precondition for her development and progress. Finally, African political leaders must vigorously invest in their country's educational systems for the long-term sustainability goals and the empowerment of their citizens.

\section{References}

[1] W. E. B. Du Bois (2021). Available at: https://www.history.com/topics/black-history/w-e-b-du-bois

[2] W.E.B. DUBIOS (2010). Available at: https://prezi.com/hcxfogmaubvp/web-dubios

[3] Aptheker, A. (1982). The Complete Published Works of W. E. B. Du Bois. New Jersey: Comp and Cel Publishers. 
[4] Garfield, G. (2014). Tightrope - a racial Journey to the age of Obama. Langham: Rowman \& Littlefield, 272.

[5] Morris, A. (2015). The Scholar Denied: W. E. B. Du Bois and the Birth of. Modern Sociology. Oakland: University of California Press, 282.

[6] Lynn, D. (2020). Surveillance, State Power, and the Activism of Shirley Graham Du Bois. Black Perspectives.

[7] Goffe, L. G. (2013). W.E.B. The Father of Modern- Pan- Africanism. New African. Available at: https://newafricanmagazine. $\operatorname{com} / 4091 /$

[8] Wolfe, R. P. (1996). The True Legacy of W. E. B. Du Bois. The Boston Globe. Available at: https://www.umass.edu/afroam/ true-legacy-w-e-b-du-bois

[9] Du Bois, W. E. B. (1899). The Philadelphia Negro: A Social Study. Philadelphia: University of Pennsylvania.

[10] Du Bois, W. E. B. (1903). The Souls of black folks. New York: Bantam.

[11] Liss, J., Du Bois, W., Boas, F. (1998). Diasporic Identities: The Science and Politics of Race in the Work of Franz Boas and W. E. B. Du Bois, 1894-1919. Cultural Anthropology, 13 (2), 127-166. doi: http://doi.org/10.1525/can.1998.13.2.127

[12] Du Bois, W. E. B. (1897). The Conservation of Races. Good Press.

[13] Zuckerman, P. (2004). The Social Theory of W. E. B. Du Bois. Pine Forge.

[14] Du Bois, W. E. B. (1904). The Development of a People. International Journal of Ethics, 14 (3), 292-311. doi: http://doi.org/ 10.1086/intejethi.14.3.2375919

[15] West, C. (2017). Race Matters. Boston: Beacon Press.

[16] Du Bois, W. E. B. (1947). The World and Africa: An Inquiry into the part which Africa has played in world history. New York: Viking Press.

[17] Adejummobi, S. A.; Mjagki, N. (Ed.) (2001). The Pan-Africanism Congress' in Organizing Black America. An encyclopedia of African American Association. New York: Garland Publishing Inc.

[18] Gobineau, A. (1967). The Inequality of Human Races. New York: H. Fertig.

[19] Du Bois, W. E. B. (1920). Dark water: voices from within the veil. New York: Humanity Books.

[20] Rex, J. (1970). Race Relations in Sociological Theory. London: Weidenfeld, 161.

[21] Brown, C.A. (2018). I'm Still Here. Black Dignity in a World Made for Whiteness. New York. Convergent Books.

[22] West, C. (2010). Keeping Faith. Philosophy and Race in America. London: Routledge.

[23] Herrnstein, R. J., Murray, C. A. (1994). The Bell Curve: Intelligence and Class Structure in American Life. Free Press, 845.

[24] Fanon, F. (1959). Dying colonialism. New York: Grove Press.

[25] Mazrui, A. (2004). Nkrumah's legacy and Africa Triple Heritage Between Globalisation and Counter-Terrorism. Accra: University Press. 62.

[26] Achebe, C. (1958). Things Fall Apart. London: Heinemann Press.

[27] Nkrumah K (1961). I speak of Freedom: A Statement of African Ideology. London: Heinemann Ltd

[28] Nkrumah, K. (1974). Neo-Colonialism: The Last Stage of Imperialism. Panaf Books.

[29] Gutto, S. B. O. (2006). Towards a new paradigm for pan-African knowledge production and application in the context of the African renaissance. International Journal of African Renaissance Studies - Multi-, Inter- and Transdisciplinarity, 1 (2), 306-323. doi: http://doi.org/10.1080/18186870608529722

[30] Battle, J., Wright, E. (2002). W. E. B. Du Bois's Talented Tenth. A Quantitative Assessment. Journal of Black Studies, 32 (6), 654-672. doi: http://doi.org/10.1177/00234702032006002

[31] Creswell, J. W., Creswell, J. D. (2018). Research Design. Qualitative, Quantitative, and Mixed Methods Approaches. Los Angeles: Sage, 275.

[32] Walliman, N. (2018). Research Methods. London: Routledge.

[33] Du Bois, W. E. B. (1906). The Second Annual Meeting of the Niagara Conference. Harpers Ferry.

[34] Rodney, W. (1973). How Europe Underdeveloped Africa. London: Bogle -L 'Overture Publications.

[35] Mazrui, A (1980). The African Condition. The Reith Lectures. London: Heinemann Press. The Scholar Denied. W. E. B. Du Bois and the Birth of modern.

[36] Southern Africa Development Community (SADC) (2001). Protocol on Politics, Defence and Security Co-Operation. SADC.

[37] Yesufu, S. (2020). Harmonising Road Transport Legislation in the SADC Region for Crime Prevention. Insight on Africa, 13 (1), 28-55. doi: http://doi.org/10.1177/0975087820965165

[38] Kistin, E.J. (2007) Trans-boundary Cooperation in SADC: From Forum to Implementation.

[39] Dr. Shirley Graham DuBois - Geni. Available at: https://www.geni.com/people/Dr-Shirley-Graham-Du Bois/6000000026938105581 